\title{
An Interview with Chung-Laung David Liu*
}

\section{by Doug Fairbairn ${ }^{\dagger}$}

As a leading computer scientist and educator for over five decades, Professor David C. L. Liu has made a great impact on both academia and the industry. Among his many amazing scientific contributions, I mention just two. David is a visionary who long ago argued that rigorous mathematics would be essential to the solution of complex engineering problems. He is true to his conviction. Using deep knowledge of combinatorial mathematics, David has transformed the methodology of Electronic Design Automation (EDA) from an ad hoc state into a thriving algorithmic discipline. As a second example, David's classic work on Rate Monotonic Scheduling is now at the heart of modern scheduling theory, essential for the design of real-time operating systems. His multitude of IEEE medals and awards, and recognitions from industries such as the Phil Kaufman Award, speak volumes about his monumental achievements.

Just as remarkable is David's reputation as a legendary teacher and educator. I had the great fortune of having David as my advisor when I studied computer science at the University of Illinois. His superb tutelage in and outside the classroom, as well as his warmth, humor and wisdom, has had a lasting beneficial influence on me. It is no wonder that over the years, many of his students have become prominent scientists themselves. David once told me that he greatly admired his teacher, the eminent mathematician Professor Gian-Carlo Rota, who always gave lectures that left the audience

* (C) 2014 Computer History Museum, Mountain View, California. www.computerhistory.org. Reference no. X7178.2014, catalog no. 102739932. Reprinted with permission.

† Staff Director, Semiconductor Special Interest Group, Computer History Museum

E-mail: dfairbairn@computerhistory.org incredibly inspired and motivated to think deeper afterwards. David clearly reached that high standard himself, and in addition with a clarity that could not be surpassed. Fittingly, Dave has received the highest accolades as an educator including the inaugural Karl V. Karlstrom Outstanding Educator Award from ACM, the IEEE Education Medal, and the Taylor L. Booth Education Award from the IEEE Computer Society.

Professor Liu has a colorful career that is still going strong. He has been a professor, university president, author of best-selling books, corporation board member, and even popular radio show host. I am proud and thankful to have David as my mentor and close friend, and always look forward to hearing of his next big adventure in life! -Andrew Yao, Tsinghua University

Doug Fairbairn: OK. We're here today at the Computer History Museum. It's Monday, June 2, 2014. I'm Doug Fairbairn, and I'm sitting here with Professor Chung Laung Liu, who has a very rich and interesting background covering many fields, including computer science, mathematics, VLSI design automation, and others, which he is going to share with us. He has been a professor, a teacher, a mentor, and perhaps also equally or more important, a husband, father, and grandfather, which he might also tell us about at the end.

\section{L. "David" Liu: Thank you.}

Fairbairn: He has been a board member and adviser to companies large and small. He's been a university president. And has been and is currently a host on a radio show.

Liu: That's correct. 


\section{An Interview with Chung-Laung David Liu*}

\section{by Doug Fairbairn ${ }^{\dagger}$}

As a leading computer scientist and educator for over five decades, Professor David C. L. Liu has made a great impact on both academia and the industry. Among his many amazing scientific contributions, I mention just two. David is a visionary who long ago argued that rigorous mathematics would be essential to the solution of complex engineering problems. He is true to his conviction. Using deep knowledge of combinatorial mathematics, David has transformed the methodology of Electronic Design Automation (EDA) from an ad hoc state into a thriving algorithmic discipline. As a second example, David's classic work on Rate Monotonic Scheduling is now at the heart of modern scheduling theory, essential for the design of real-time operating systems. His multitude of IEEE medals and awards, and recognitions from industries such as the Phil Kaufman Award, speak volumes about his monumental achievements.

Just as remarkable is David's reputation as a legendary teacher and educator. I had the great fortune of having David as my advisor when I studied computer science at the University of Illinois. His superb tutelage in and outside the classroom, as well as his warmth, humor and wisdom, has had a lasting beneficial influence on me. It is no wonder that over the years, many of his students have become prominent scientists themselves. David once told me that he greatly admired his teacher, the eminent mathematician Professor Gian-Carlo Rota, who always gave lectures that left the audience

* (C) 2014 Computer History Museum, Mountain View, California. www.computerhistory.org. Reference no. X7178.2014, catalog no. 102739932. Reprinted with permission.

† Staff Director, Semiconductor Special Interest Group, Computer History Museum

E-mail: dfairbairn@computerhistory.org incredibly inspired and motivated to think deeper afterwards. David clearly reached that high standard himself, and in addition with a clarity that could not be surpassed. Fittingly, Dave has received the highest accolades as an educator including the inaugural Karl V. Karlstrom Outstanding Educator Award from ACM, the IEEE Education Medal, and the Taylor L. Booth Education Award from the IEEE Computer Society.

Professor Liu has a colorful career that is still going strong. He has been a professor, university president, author of best-selling books, corporation board member, and even popular radio show host. I am proud and thankful to have David as my mentor and close friend, and always look forward to hearing of his next big adventure in life! -Andrew Yao, Tsinghua University

Doug Fairbairn: OK. We're here today at the Computer History Museum. It's Monday, June 2, 2014. I'm Doug Fairbairn, and I'm sitting here with Professor Chung Laung Liu, who has a very rich and interesting background covering many fields, including computer science, mathematics, VLSI design automation, and others, which he is going to share with us. He has been a professor, a teacher, a mentor, and perhaps also equally or more important, a husband, father, and grandfather, which he might also tell us about at the end.

\section{L. "David" Liu: Thank you.}

Fairbairn: He has been a board member and adviser to companies large and small. He's been a university president. And has been and is currently a host on a radio show.

Liu: That's correct. 


\section{An Interview with Chung-Laung David Liu*}

\section{by Doug Fairbairn ${ }^{\dagger}$}

As a leading computer scientist and educator for over five decades, Professor David C. L. Liu has made a great impact on both academia and the industry. Among his many amazing scientific contributions, I mention just two. David is a visionary who long ago argued that rigorous mathematics would be essential to the solution of complex engineering problems. He is true to his conviction. Using deep knowledge of combinatorial mathematics, David has transformed the methodology of Electronic Design Automation (EDA) from an ad hoc state into a thriving algorithmic discipline. As a second example, David's classic work on Rate Monotonic Scheduling is now at the heart of modern scheduling theory, essential for the design of real-time operating systems. His multitude of IEEE medals and awards, and recognitions from industries such as the Phil Kaufman Award, speak volumes about his monumental achievements.

Just as remarkable is David's reputation as a legendary teacher and educator. I had the great fortune of having David as my advisor when I studied computer science at the University of Illinois. His superb tutelage in and outside the classroom, as well as his warmth, humor and wisdom, has had a lasting beneficial influence on me. It is no wonder that over the years, many of his students have become prominent scientists themselves. David once told me that he greatly admired his teacher, the eminent mathematician Professor Gian-Carlo Rota, who always gave lectures that left the audience

* (C) 2014 Computer History Museum, Mountain View, California. www.computerhistory.org. Reference no. X7178.2014, catalog no. 102739932. Reprinted with permission.

† Staff Director, Semiconductor Special Interest Group, Computer History Museum

E-mail: dfairbairn@computerhistory.org incredibly inspired and motivated to think deeper afterwards. David clearly reached that high standard himself, and in addition with a clarity that could not be surpassed. Fittingly, Dave has received the highest accolades as an educator including the inaugural Karl V. Karlstrom Outstanding Educator Award from ACM, the IEEE Education Medal, and the Taylor L. Booth Education Award from the IEEE Computer Society.

Professor Liu has a colorful career that is still going strong. He has been a professor, university president, author of best-selling books, corporation board member, and even popular radio show host. I am proud and thankful to have David as my mentor and close friend, and always look forward to hearing of his next big adventure in life! -Andrew Yao, Tsinghua University

Doug Fairbairn: OK. We're here today at the Computer History Museum. It's Monday, June 2, 2014. I'm Doug Fairbairn, and I'm sitting here with Professor Chung Laung Liu, who has a very rich and interesting background covering many fields, including computer science, mathematics, VLSI design automation, and others, which he is going to share with us. He has been a professor, a teacher, a mentor, and perhaps also equally or more important, a husband, father, and grandfather, which he might also tell us about at the end.

\section{L. "David" Liu: Thank you.}

Fairbairn: He has been a board member and adviser to companies large and small. He's been a university president. And has been and is currently a host on a radio show.

Liu: That's correct. 


\section{An Interview with Chung-Laung David Liu*}

\section{by Doug Fairbairn ${ }^{\dagger}$}

As a leading computer scientist and educator for over five decades, Professor David C. L. Liu has made a great impact on both academia and the industry. Among his many amazing scientific contributions, I mention just two. David is a visionary who long ago argued that rigorous mathematics would be essential to the solution of complex engineering problems. He is true to his conviction. Using deep knowledge of combinatorial mathematics, David has transformed the methodology of Electronic Design Automation (EDA) from an ad hoc state into a thriving algorithmic discipline. As a second example, David's classic work on Rate Monotonic Scheduling is now at the heart of modern scheduling theory, essential for the design of real-time operating systems. His multitude of IEEE medals and awards, and recognitions from industries such as the Phil Kaufman Award, speak volumes about his monumental achievements.

Just as remarkable is David's reputation as a legendary teacher and educator. I had the great fortune of having David as my advisor when I studied computer science at the University of Illinois. His superb tutelage in and outside the classroom, as well as his warmth, humor and wisdom, has had a lasting beneficial influence on me. It is no wonder that over the years, many of his students have become prominent scientists themselves. David once told me that he greatly admired his teacher, the eminent mathematician Professor Gian-Carlo Rota, who always gave lectures that left the audience

* (C) 2014 Computer History Museum, Mountain View, California. www.computerhistory.org. Reference no. X7178.2014, catalog no. 102739932. Reprinted with permission.

† Staff Director, Semiconductor Special Interest Group, Computer History Museum

E-mail: dfairbairn@computerhistory.org incredibly inspired and motivated to think deeper afterwards. David clearly reached that high standard himself, and in addition with a clarity that could not be surpassed. Fittingly, Dave has received the highest accolades as an educator including the inaugural Karl V. Karlstrom Outstanding Educator Award from ACM, the IEEE Education Medal, and the Taylor L. Booth Education Award from the IEEE Computer Society.

Professor Liu has a colorful career that is still going strong. He has been a professor, university president, author of best-selling books, corporation board member, and even popular radio show host. I am proud and thankful to have David as my mentor and close friend, and always look forward to hearing of his next big adventure in life! -Andrew Yao, Tsinghua University

Doug Fairbairn: OK. We're here today at the Computer History Museum. It's Monday, June 2, 2014. I'm Doug Fairbairn, and I'm sitting here with Professor Chung Laung Liu, who has a very rich and interesting background covering many fields, including computer science, mathematics, VLSI design automation, and others, which he is going to share with us. He has been a professor, a teacher, a mentor, and perhaps also equally or more important, a husband, father, and grandfather, which he might also tell us about at the end.

\section{L. "David" Liu: Thank you.}

Fairbairn: He has been a board member and adviser to companies large and small. He's been a university president. And has been and is currently a host on a radio show.

Liu: That's correct. 


\section{An Interview with Chung-Laung David Liu*}

\section{by Doug Fairbairn ${ }^{\dagger}$}

As a leading computer scientist and educator for over five decades, Professor David C. L. Liu has made a great impact on both academia and the industry. Among his many amazing scientific contributions, I mention just two. David is a visionary who long ago argued that rigorous mathematics would be essential to the solution of complex engineering problems. He is true to his conviction. Using deep knowledge of combinatorial mathematics, David has transformed the methodology of Electronic Design Automation (EDA) from an ad hoc state into a thriving algorithmic discipline. As a second example, David's classic work on Rate Monotonic Scheduling is now at the heart of modern scheduling theory, essential for the design of real-time operating systems. His multitude of IEEE medals and awards, and recognitions from industries such as the Phil Kaufman Award, speak volumes about his monumental achievements.

Just as remarkable is David's reputation as a legendary teacher and educator. I had the great fortune of having David as my advisor when I studied computer science at the University of Illinois. His superb tutelage in and outside the classroom, as well as his warmth, humor and wisdom, has had a lasting beneficial influence on me. It is no wonder that over the years, many of his students have become prominent scientists themselves. David once told me that he greatly admired his teacher, the eminent mathematician Professor Gian-Carlo Rota, who always gave lectures that left the audience

* (C) 2014 Computer History Museum, Mountain View, California. www.computerhistory.org. Reference no. X7178.2014, catalog no. 102739932. Reprinted with permission.

† Staff Director, Semiconductor Special Interest Group, Computer History Museum

E-mail: dfairbairn@computerhistory.org incredibly inspired and motivated to think deeper afterwards. David clearly reached that high standard himself, and in addition with a clarity that could not be surpassed. Fittingly, Dave has received the highest accolades as an educator including the inaugural Karl V. Karlstrom Outstanding Educator Award from ACM, the IEEE Education Medal, and the Taylor L. Booth Education Award from the IEEE Computer Society.

Professor Liu has a colorful career that is still going strong. He has been a professor, university president, author of best-selling books, corporation board member, and even popular radio show host. I am proud and thankful to have David as my mentor and close friend, and always look forward to hearing of his next big adventure in life! -Andrew Yao, Tsinghua University

Doug Fairbairn: OK. We're here today at the Computer History Museum. It's Monday, June 2, 2014. I'm Doug Fairbairn, and I'm sitting here with Professor Chung Laung Liu, who has a very rich and interesting background covering many fields, including computer science, mathematics, VLSI design automation, and others, which he is going to share with us. He has been a professor, a teacher, a mentor, and perhaps also equally or more important, a husband, father, and grandfather, which he might also tell us about at the end.

\section{L. "David" Liu: Thank you.}

Fairbairn: He has been a board member and adviser to companies large and small. He's been a university president. And has been and is currently a host on a radio show.

Liu: That's correct. 


\section{An Interview with Chung-Laung David Liu*}

\section{by Doug Fairbairn ${ }^{\dagger}$}

As a leading computer scientist and educator for over five decades, Professor David C. L. Liu has made a great impact on both academia and the industry. Among his many amazing scientific contributions, I mention just two. David is a visionary who long ago argued that rigorous mathematics would be essential to the solution of complex engineering problems. He is true to his conviction. Using deep knowledge of combinatorial mathematics, David has transformed the methodology of Electronic Design Automation (EDA) from an ad hoc state into a thriving algorithmic discipline. As a second example, David's classic work on Rate Monotonic Scheduling is now at the heart of modern scheduling theory, essential for the design of real-time operating systems. His multitude of IEEE medals and awards, and recognitions from industries such as the Phil Kaufman Award, speak volumes about his monumental achievements.

Just as remarkable is David's reputation as a legendary teacher and educator. I had the great fortune of having David as my advisor when I studied computer science at the University of Illinois. His superb tutelage in and outside the classroom, as well as his warmth, humor and wisdom, has had a lasting beneficial influence on me. It is no wonder that over the years, many of his students have become prominent scientists themselves. David once told me that he greatly admired his teacher, the eminent mathematician Professor Gian-Carlo Rota, who always gave lectures that left the audience

* (C) 2014 Computer History Museum, Mountain View, California. www.computerhistory.org. Reference no. X7178.2014, catalog no. 102739932. Reprinted with permission.

† Staff Director, Semiconductor Special Interest Group, Computer History Museum

E-mail: dfairbairn@computerhistory.org incredibly inspired and motivated to think deeper afterwards. David clearly reached that high standard himself, and in addition with a clarity that could not be surpassed. Fittingly, Dave has received the highest accolades as an educator including the inaugural Karl V. Karlstrom Outstanding Educator Award from ACM, the IEEE Education Medal, and the Taylor L. Booth Education Award from the IEEE Computer Society.

Professor Liu has a colorful career that is still going strong. He has been a professor, university president, author of best-selling books, corporation board member, and even popular radio show host. I am proud and thankful to have David as my mentor and close friend, and always look forward to hearing of his next big adventure in life! -Andrew Yao, Tsinghua University

Doug Fairbairn: OK. We're here today at the Computer History Museum. It's Monday, June 2, 2014. I'm Doug Fairbairn, and I'm sitting here with Professor Chung Laung Liu, who has a very rich and interesting background covering many fields, including computer science, mathematics, VLSI design automation, and others, which he is going to share with us. He has been a professor, a teacher, a mentor, and perhaps also equally or more important, a husband, father, and grandfather, which he might also tell us about at the end.

\section{L. "David" Liu: Thank you.}

Fairbairn: He has been a board member and adviser to companies large and small. He's been a university president. And has been and is currently a host on a radio show.

Liu: That's correct. 


\section{An Interview with Chung-Laung David Liu*}

\section{by Doug Fairbairn ${ }^{\dagger}$}

As a leading computer scientist and educator for over five decades, Professor David C. L. Liu has made a great impact on both academia and the industry. Among his many amazing scientific contributions, I mention just two. David is a visionary who long ago argued that rigorous mathematics would be essential to the solution of complex engineering problems. He is true to his conviction. Using deep knowledge of combinatorial mathematics, David has transformed the methodology of Electronic Design Automation (EDA) from an ad hoc state into a thriving algorithmic discipline. As a second example, David's classic work on Rate Monotonic Scheduling is now at the heart of modern scheduling theory, essential for the design of real-time operating systems. His multitude of IEEE medals and awards, and recognitions from industries such as the Phil Kaufman Award, speak volumes about his monumental achievements.

Just as remarkable is David's reputation as a legendary teacher and educator. I had the great fortune of having David as my advisor when I studied computer science at the University of Illinois. His superb tutelage in and outside the classroom, as well as his warmth, humor and wisdom, has had a lasting beneficial influence on me. It is no wonder that over the years, many of his students have become prominent scientists themselves. David once told me that he greatly admired his teacher, the eminent mathematician Professor Gian-Carlo Rota, who always gave lectures that left the audience

* (C) 2014 Computer History Museum, Mountain View, California. www.computerhistory.org. Reference no. X7178.2014, catalog no. 102739932. Reprinted with permission.

† Staff Director, Semiconductor Special Interest Group, Computer History Museum

E-mail: dfairbairn@computerhistory.org incredibly inspired and motivated to think deeper afterwards. David clearly reached that high standard himself, and in addition with a clarity that could not be surpassed. Fittingly, Dave has received the highest accolades as an educator including the inaugural Karl V. Karlstrom Outstanding Educator Award from ACM, the IEEE Education Medal, and the Taylor L. Booth Education Award from the IEEE Computer Society.

Professor Liu has a colorful career that is still going strong. He has been a professor, university president, author of best-selling books, corporation board member, and even popular radio show host. I am proud and thankful to have David as my mentor and close friend, and always look forward to hearing of his next big adventure in life! -Andrew Yao, Tsinghua University

Doug Fairbairn: OK. We're here today at the Computer History Museum. It's Monday, June 2, 2014. I'm Doug Fairbairn, and I'm sitting here with Professor Chung Laung Liu, who has a very rich and interesting background covering many fields, including computer science, mathematics, VLSI design automation, and others, which he is going to share with us. He has been a professor, a teacher, a mentor, and perhaps also equally or more important, a husband, father, and grandfather, which he might also tell us about at the end.

\section{L. "David" Liu: Thank you.}

Fairbairn: He has been a board member and adviser to companies large and small. He's been a university president. And has been and is currently a host on a radio show.

Liu: That's correct. 


\section{An Interview with Chung-Laung David Liu*}

\section{by Doug Fairbairn ${ }^{\dagger}$}

As a leading computer scientist and educator for over five decades, Professor David C. L. Liu has made a great impact on both academia and the industry. Among his many amazing scientific contributions, I mention just two. David is a visionary who long ago argued that rigorous mathematics would be essential to the solution of complex engineering problems. He is true to his conviction. Using deep knowledge of combinatorial mathematics, David has transformed the methodology of Electronic Design Automation (EDA) from an ad hoc state into a thriving algorithmic discipline. As a second example, David's classic work on Rate Monotonic Scheduling is now at the heart of modern scheduling theory, essential for the design of real-time operating systems. His multitude of IEEE medals and awards, and recognitions from industries such as the Phil Kaufman Award, speak volumes about his monumental achievements.

Just as remarkable is David's reputation as a legendary teacher and educator. I had the great fortune of having David as my advisor when I studied computer science at the University of Illinois. His superb tutelage in and outside the classroom, as well as his warmth, humor and wisdom, has had a lasting beneficial influence on me. It is no wonder that over the years, many of his students have become prominent scientists themselves. David once told me that he greatly admired his teacher, the eminent mathematician Professor Gian-Carlo Rota, who always gave lectures that left the audience

* (C) 2014 Computer History Museum, Mountain View, California. www.computerhistory.org. Reference no. X7178.2014, catalog no. 102739932. Reprinted with permission.

† Staff Director, Semiconductor Special Interest Group, Computer History Museum

E-mail: dfairbairn@computerhistory.org incredibly inspired and motivated to think deeper afterwards. David clearly reached that high standard himself, and in addition with a clarity that could not be surpassed. Fittingly, Dave has received the highest accolades as an educator including the inaugural Karl V. Karlstrom Outstanding Educator Award from ACM, the IEEE Education Medal, and the Taylor L. Booth Education Award from the IEEE Computer Society.

Professor Liu has a colorful career that is still going strong. He has been a professor, university president, author of best-selling books, corporation board member, and even popular radio show host. I am proud and thankful to have David as my mentor and close friend, and always look forward to hearing of his next big adventure in life! -Andrew Yao, Tsinghua University

Doug Fairbairn: OK. We're here today at the Computer History Museum. It's Monday, June 2, 2014. I'm Doug Fairbairn, and I'm sitting here with Professor Chung Laung Liu, who has a very rich and interesting background covering many fields, including computer science, mathematics, VLSI design automation, and others, which he is going to share with us. He has been a professor, a teacher, a mentor, and perhaps also equally or more important, a husband, father, and grandfather, which he might also tell us about at the end.

\section{L. "David" Liu: Thank you.}

Fairbairn: He has been a board member and adviser to companies large and small. He's been a university president. And has been and is currently a host on a radio show.

Liu: That's correct. 


\section{An Interview with Chung-Laung David Liu*}

\section{by Doug Fairbairn ${ }^{\dagger}$}

As a leading computer scientist and educator for over five decades, Professor David C. L. Liu has made a great impact on both academia and the industry. Among his many amazing scientific contributions, I mention just two. David is a visionary who long ago argued that rigorous mathematics would be essential to the solution of complex engineering problems. He is true to his conviction. Using deep knowledge of combinatorial mathematics, David has transformed the methodology of Electronic Design Automation (EDA) from an ad hoc state into a thriving algorithmic discipline. As a second example, David's classic work on Rate Monotonic Scheduling is now at the heart of modern scheduling theory, essential for the design of real-time operating systems. His multitude of IEEE medals and awards, and recognitions from industries such as the Phil Kaufman Award, speak volumes about his monumental achievements.

Just as remarkable is David's reputation as a legendary teacher and educator. I had the great fortune of having David as my advisor when I studied computer science at the University of Illinois. His superb tutelage in and outside the classroom, as well as his warmth, humor and wisdom, has had a lasting beneficial influence on me. It is no wonder that over the years, many of his students have become prominent scientists themselves. David once told me that he greatly admired his teacher, the eminent mathematician Professor Gian-Carlo Rota, who always gave lectures that left the audience

* (C) 2014 Computer History Museum, Mountain View, California. www.computerhistory.org. Reference no. X7178.2014, catalog no. 102739932. Reprinted with permission.

† Staff Director, Semiconductor Special Interest Group, Computer History Museum

E-mail: dfairbairn@computerhistory.org incredibly inspired and motivated to think deeper afterwards. David clearly reached that high standard himself, and in addition with a clarity that could not be surpassed. Fittingly, Dave has received the highest accolades as an educator including the inaugural Karl V. Karlstrom Outstanding Educator Award from ACM, the IEEE Education Medal, and the Taylor L. Booth Education Award from the IEEE Computer Society.

Professor Liu has a colorful career that is still going strong. He has been a professor, university president, author of best-selling books, corporation board member, and even popular radio show host. I am proud and thankful to have David as my mentor and close friend, and always look forward to hearing of his next big adventure in life! -Andrew Yao, Tsinghua University

Doug Fairbairn: OK. We're here today at the Computer History Museum. It's Monday, June 2, 2014. I'm Doug Fairbairn, and I'm sitting here with Professor Chung Laung Liu, who has a very rich and interesting background covering many fields, including computer science, mathematics, VLSI design automation, and others, which he is going to share with us. He has been a professor, a teacher, a mentor, and perhaps also equally or more important, a husband, father, and grandfather, which he might also tell us about at the end.

\section{L. "David" Liu: Thank you.}

Fairbairn: He has been a board member and adviser to companies large and small. He's been a university president. And has been and is currently a host on a radio show.

Liu: That's correct. 


\section{An Interview with Chung-Laung David Liu*}

\section{by Doug Fairbairn ${ }^{\dagger}$}

As a leading computer scientist and educator for over five decades, Professor David C. L. Liu has made a great impact on both academia and the industry. Among his many amazing scientific contributions, I mention just two. David is a visionary who long ago argued that rigorous mathematics would be essential to the solution of complex engineering problems. He is true to his conviction. Using deep knowledge of combinatorial mathematics, David has transformed the methodology of Electronic Design Automation (EDA) from an ad hoc state into a thriving algorithmic discipline. As a second example, David's classic work on Rate Monotonic Scheduling is now at the heart of modern scheduling theory, essential for the design of real-time operating systems. His multitude of IEEE medals and awards, and recognitions from industries such as the Phil Kaufman Award, speak volumes about his monumental achievements.

Just as remarkable is David's reputation as a legendary teacher and educator. I had the great fortune of having David as my advisor when I studied computer science at the University of Illinois. His superb tutelage in and outside the classroom, as well as his warmth, humor and wisdom, has had a lasting beneficial influence on me. It is no wonder that over the years, many of his students have become prominent scientists themselves. David once told me that he greatly admired his teacher, the eminent mathematician Professor Gian-Carlo Rota, who always gave lectures that left the audience

* (C) 2014 Computer History Museum, Mountain View, California. www.computerhistory.org. Reference no. X7178.2014, catalog no. 102739932. Reprinted with permission.

† Staff Director, Semiconductor Special Interest Group, Computer History Museum

E-mail: dfairbairn@computerhistory.org incredibly inspired and motivated to think deeper afterwards. David clearly reached that high standard himself, and in addition with a clarity that could not be surpassed. Fittingly, Dave has received the highest accolades as an educator including the inaugural Karl V. Karlstrom Outstanding Educator Award from ACM, the IEEE Education Medal, and the Taylor L. Booth Education Award from the IEEE Computer Society.

Professor Liu has a colorful career that is still going strong. He has been a professor, university president, author of best-selling books, corporation board member, and even popular radio show host. I am proud and thankful to have David as my mentor and close friend, and always look forward to hearing of his next big adventure in life! -Andrew Yao, Tsinghua University

Doug Fairbairn: OK. We're here today at the Computer History Museum. It's Monday, June 2, 2014. I'm Doug Fairbairn, and I'm sitting here with Professor Chung Laung Liu, who has a very rich and interesting background covering many fields, including computer science, mathematics, VLSI design automation, and others, which he is going to share with us. He has been a professor, a teacher, a mentor, and perhaps also equally or more important, a husband, father, and grandfather, which he might also tell us about at the end.

\section{L. "David" Liu: Thank you.}

Fairbairn: He has been a board member and adviser to companies large and small. He's been a university president. And has been and is currently a host on a radio show.

Liu: That's correct. 


\section{An Interview with Chung-Laung David Liu*}

\section{by Doug Fairbairn ${ }^{\dagger}$}

As a leading computer scientist and educator for over five decades, Professor David C. L. Liu has made a great impact on both academia and the industry. Among his many amazing scientific contributions, I mention just two. David is a visionary who long ago argued that rigorous mathematics would be essential to the solution of complex engineering problems. He is true to his conviction. Using deep knowledge of combinatorial mathematics, David has transformed the methodology of Electronic Design Automation (EDA) from an ad hoc state into a thriving algorithmic discipline. As a second example, David's classic work on Rate Monotonic Scheduling is now at the heart of modern scheduling theory, essential for the design of real-time operating systems. His multitude of IEEE medals and awards, and recognitions from industries such as the Phil Kaufman Award, speak volumes about his monumental achievements.

Just as remarkable is David's reputation as a legendary teacher and educator. I had the great fortune of having David as my advisor when I studied computer science at the University of Illinois. His superb tutelage in and outside the classroom, as well as his warmth, humor and wisdom, has had a lasting beneficial influence on me. It is no wonder that over the years, many of his students have become prominent scientists themselves. David once told me that he greatly admired his teacher, the eminent mathematician Professor Gian-Carlo Rota, who always gave lectures that left the audience

* (C) 2014 Computer History Museum, Mountain View, California. www.computerhistory.org. Reference no. X7178.2014, catalog no. 102739932. Reprinted with permission.

† Staff Director, Semiconductor Special Interest Group, Computer History Museum

E-mail: dfairbairn@computerhistory.org incredibly inspired and motivated to think deeper afterwards. David clearly reached that high standard himself, and in addition with a clarity that could not be surpassed. Fittingly, Dave has received the highest accolades as an educator including the inaugural Karl V. Karlstrom Outstanding Educator Award from ACM, the IEEE Education Medal, and the Taylor L. Booth Education Award from the IEEE Computer Society.

Professor Liu has a colorful career that is still going strong. He has been a professor, university president, author of best-selling books, corporation board member, and even popular radio show host. I am proud and thankful to have David as my mentor and close friend, and always look forward to hearing of his next big adventure in life! -Andrew Yao, Tsinghua University

Doug Fairbairn: OK. We're here today at the Computer History Museum. It's Monday, June 2, 2014. I'm Doug Fairbairn, and I'm sitting here with Professor Chung Laung Liu, who has a very rich and interesting background covering many fields, including computer science, mathematics, VLSI design automation, and others, which he is going to share with us. He has been a professor, a teacher, a mentor, and perhaps also equally or more important, a husband, father, and grandfather, which he might also tell us about at the end.

\section{L. "David" Liu: Thank you.}

Fairbairn: He has been a board member and adviser to companies large and small. He's been a university president. And has been and is currently a host on a radio show.

Liu: That's correct. 


\section{An Interview with Chung-Laung David Liu*}

\section{by Doug Fairbairn ${ }^{\dagger}$}

As a leading computer scientist and educator for over five decades, Professor David C. L. Liu has made a great impact on both academia and the industry. Among his many amazing scientific contributions, I mention just two. David is a visionary who long ago argued that rigorous mathematics would be essential to the solution of complex engineering problems. He is true to his conviction. Using deep knowledge of combinatorial mathematics, David has transformed the methodology of Electronic Design Automation (EDA) from an ad hoc state into a thriving algorithmic discipline. As a second example, David's classic work on Rate Monotonic Scheduling is now at the heart of modern scheduling theory, essential for the design of real-time operating systems. His multitude of IEEE medals and awards, and recognitions from industries such as the Phil Kaufman Award, speak volumes about his monumental achievements.

Just as remarkable is David's reputation as a legendary teacher and educator. I had the great fortune of having David as my advisor when I studied computer science at the University of Illinois. His superb tutelage in and outside the classroom, as well as his warmth, humor and wisdom, has had a lasting beneficial influence on me. It is no wonder that over the years, many of his students have become prominent scientists themselves. David once told me that he greatly admired his teacher, the eminent mathematician Professor Gian-Carlo Rota, who always gave lectures that left the audience

* (C) 2014 Computer History Museum, Mountain View, California. www.computerhistory.org. Reference no. X7178.2014, catalog no. 102739932. Reprinted with permission.

† Staff Director, Semiconductor Special Interest Group, Computer History Museum

E-mail: dfairbairn@computerhistory.org incredibly inspired and motivated to think deeper afterwards. David clearly reached that high standard himself, and in addition with a clarity that could not be surpassed. Fittingly, Dave has received the highest accolades as an educator including the inaugural Karl V. Karlstrom Outstanding Educator Award from ACM, the IEEE Education Medal, and the Taylor L. Booth Education Award from the IEEE Computer Society.

Professor Liu has a colorful career that is still going strong. He has been a professor, university president, author of best-selling books, corporation board member, and even popular radio show host. I am proud and thankful to have David as my mentor and close friend, and always look forward to hearing of his next big adventure in life! -Andrew Yao, Tsinghua University

Doug Fairbairn: OK. We're here today at the Computer History Museum. It's Monday, June 2, 2014. I'm Doug Fairbairn, and I'm sitting here with Professor Chung Laung Liu, who has a very rich and interesting background covering many fields, including computer science, mathematics, VLSI design automation, and others, which he is going to share with us. He has been a professor, a teacher, a mentor, and perhaps also equally or more important, a husband, father, and grandfather, which he might also tell us about at the end.

\section{L. "David" Liu: Thank you.}

Fairbairn: He has been a board member and adviser to companies large and small. He's been a university president. And has been and is currently a host on a radio show.

Liu: That's correct. 


\section{An Interview with Chung-Laung David Liu*}

\section{by Doug Fairbairn ${ }^{\dagger}$}

As a leading computer scientist and educator for over five decades, Professor David C. L. Liu has made a great impact on both academia and the industry. Among his many amazing scientific contributions, I mention just two. David is a visionary who long ago argued that rigorous mathematics would be essential to the solution of complex engineering problems. He is true to his conviction. Using deep knowledge of combinatorial mathematics, David has transformed the methodology of Electronic Design Automation (EDA) from an ad hoc state into a thriving algorithmic discipline. As a second example, David's classic work on Rate Monotonic Scheduling is now at the heart of modern scheduling theory, essential for the design of real-time operating systems. His multitude of IEEE medals and awards, and recognitions from industries such as the Phil Kaufman Award, speak volumes about his monumental achievements.

Just as remarkable is David's reputation as a legendary teacher and educator. I had the great fortune of having David as my advisor when I studied computer science at the University of Illinois. His superb tutelage in and outside the classroom, as well as his warmth, humor and wisdom, has had a lasting beneficial influence on me. It is no wonder that over the years, many of his students have become prominent scientists themselves. David once told me that he greatly admired his teacher, the eminent mathematician Professor Gian-Carlo Rota, who always gave lectures that left the audience

* (C) 2014 Computer History Museum, Mountain View, California. www.computerhistory.org. Reference no. X7178.2014, catalog no. 102739932. Reprinted with permission.

† Staff Director, Semiconductor Special Interest Group, Computer History Museum

E-mail: dfairbairn@computerhistory.org incredibly inspired and motivated to think deeper afterwards. David clearly reached that high standard himself, and in addition with a clarity that could not be surpassed. Fittingly, Dave has received the highest accolades as an educator including the inaugural Karl V. Karlstrom Outstanding Educator Award from ACM, the IEEE Education Medal, and the Taylor L. Booth Education Award from the IEEE Computer Society.

Professor Liu has a colorful career that is still going strong. He has been a professor, university president, author of best-selling books, corporation board member, and even popular radio show host. I am proud and thankful to have David as my mentor and close friend, and always look forward to hearing of his next big adventure in life! -Andrew Yao, Tsinghua University

Doug Fairbairn: OK. We're here today at the Computer History Museum. It's Monday, June 2, 2014. I'm Doug Fairbairn, and I'm sitting here with Professor Chung Laung Liu, who has a very rich and interesting background covering many fields, including computer science, mathematics, VLSI design automation, and others, which he is going to share with us. He has been a professor, a teacher, a mentor, and perhaps also equally or more important, a husband, father, and grandfather, which he might also tell us about at the end.

\section{L. "David" Liu: Thank you.}

Fairbairn: He has been a board member and adviser to companies large and small. He's been a university president. And has been and is currently a host on a radio show.

Liu: That's correct. 


\section{An Interview with Chung-Laung David Liu*}

\section{by Doug Fairbairn ${ }^{\dagger}$}

As a leading computer scientist and educator for over five decades, Professor David C. L. Liu has made a great impact on both academia and the industry. Among his many amazing scientific contributions, I mention just two. David is a visionary who long ago argued that rigorous mathematics would be essential to the solution of complex engineering problems. He is true to his conviction. Using deep knowledge of combinatorial mathematics, David has transformed the methodology of Electronic Design Automation (EDA) from an ad hoc state into a thriving algorithmic discipline. As a second example, David's classic work on Rate Monotonic Scheduling is now at the heart of modern scheduling theory, essential for the design of real-time operating systems. His multitude of IEEE medals and awards, and recognitions from industries such as the Phil Kaufman Award, speak volumes about his monumental achievements.

Just as remarkable is David's reputation as a legendary teacher and educator. I had the great fortune of having David as my advisor when I studied computer science at the University of Illinois. His superb tutelage in and outside the classroom, as well as his warmth, humor and wisdom, has had a lasting beneficial influence on me. It is no wonder that over the years, many of his students have become prominent scientists themselves. David once told me that he greatly admired his teacher, the eminent mathematician Professor Gian-Carlo Rota, who always gave lectures that left the audience

* (C) 2014 Computer History Museum, Mountain View, California. www.computerhistory.org. Reference no. X7178.2014, catalog no. 102739932. Reprinted with permission.

† Staff Director, Semiconductor Special Interest Group, Computer History Museum

E-mail: dfairbairn@computerhistory.org incredibly inspired and motivated to think deeper afterwards. David clearly reached that high standard himself, and in addition with a clarity that could not be surpassed. Fittingly, Dave has received the highest accolades as an educator including the inaugural Karl V. Karlstrom Outstanding Educator Award from ACM, the IEEE Education Medal, and the Taylor L. Booth Education Award from the IEEE Computer Society.

Professor Liu has a colorful career that is still going strong. He has been a professor, university president, author of best-selling books, corporation board member, and even popular radio show host. I am proud and thankful to have David as my mentor and close friend, and always look forward to hearing of his next big adventure in life! -Andrew Yao, Tsinghua University

Doug Fairbairn: OK. We're here today at the Computer History Museum. It's Monday, June 2, 2014. I'm Doug Fairbairn, and I'm sitting here with Professor Chung Laung Liu, who has a very rich and interesting background covering many fields, including computer science, mathematics, VLSI design automation, and others, which he is going to share with us. He has been a professor, a teacher, a mentor, and perhaps also equally or more important, a husband, father, and grandfather, which he might also tell us about at the end.

\section{L. "David" Liu: Thank you.}

Fairbairn: He has been a board member and adviser to companies large and small. He's been a university president. And has been and is currently a host on a radio show.

Liu: That's correct. 


\section{An Interview with Chung-Laung David Liu*}

\section{by Doug Fairbairn ${ }^{\dagger}$}

As a leading computer scientist and educator for over five decades, Professor David C. L. Liu has made a great impact on both academia and the industry. Among his many amazing scientific contributions, I mention just two. David is a visionary who long ago argued that rigorous mathematics would be essential to the solution of complex engineering problems. He is true to his conviction. Using deep knowledge of combinatorial mathematics, David has transformed the methodology of Electronic Design Automation (EDA) from an ad hoc state into a thriving algorithmic discipline. As a second example, David's classic work on Rate Monotonic Scheduling is now at the heart of modern scheduling theory, essential for the design of real-time operating systems. His multitude of IEEE medals and awards, and recognitions from industries such as the Phil Kaufman Award, speak volumes about his monumental achievements.

Just as remarkable is David's reputation as a legendary teacher and educator. I had the great fortune of having David as my advisor when I studied computer science at the University of Illinois. His superb tutelage in and outside the classroom, as well as his warmth, humor and wisdom, has had a lasting beneficial influence on me. It is no wonder that over the years, many of his students have become prominent scientists themselves. David once told me that he greatly admired his teacher, the eminent mathematician Professor Gian-Carlo Rota, who always gave lectures that left the audience

* (C) 2014 Computer History Museum, Mountain View, California. www.computerhistory.org. Reference no. X7178.2014, catalog no. 102739932. Reprinted with permission.

† Staff Director, Semiconductor Special Interest Group, Computer History Museum

E-mail: dfairbairn@computerhistory.org incredibly inspired and motivated to think deeper afterwards. David clearly reached that high standard himself, and in addition with a clarity that could not be surpassed. Fittingly, Dave has received the highest accolades as an educator including the inaugural Karl V. Karlstrom Outstanding Educator Award from ACM, the IEEE Education Medal, and the Taylor L. Booth Education Award from the IEEE Computer Society.

Professor Liu has a colorful career that is still going strong. He has been a professor, university president, author of best-selling books, corporation board member, and even popular radio show host. I am proud and thankful to have David as my mentor and close friend, and always look forward to hearing of his next big adventure in life! -Andrew Yao, Tsinghua University

Doug Fairbairn: OK. We're here today at the Computer History Museum. It's Monday, June 2, 2014. I'm Doug Fairbairn, and I'm sitting here with Professor Chung Laung Liu, who has a very rich and interesting background covering many fields, including computer science, mathematics, VLSI design automation, and others, which he is going to share with us. He has been a professor, a teacher, a mentor, and perhaps also equally or more important, a husband, father, and grandfather, which he might also tell us about at the end.

\section{L. "David" Liu: Thank you.}

Fairbairn: He has been a board member and adviser to companies large and small. He's been a university president. And has been and is currently a host on a radio show.

Liu: That's correct. 


\section{An Interview with Chung-Laung David Liu*}

\section{by Doug Fairbairn ${ }^{\dagger}$}

As a leading computer scientist and educator for over five decades, Professor David C. L. Liu has made a great impact on both academia and the industry. Among his many amazing scientific contributions, I mention just two. David is a visionary who long ago argued that rigorous mathematics would be essential to the solution of complex engineering problems. He is true to his conviction. Using deep knowledge of combinatorial mathematics, David has transformed the methodology of Electronic Design Automation (EDA) from an ad hoc state into a thriving algorithmic discipline. As a second example, David's classic work on Rate Monotonic Scheduling is now at the heart of modern scheduling theory, essential for the design of real-time operating systems. His multitude of IEEE medals and awards, and recognitions from industries such as the Phil Kaufman Award, speak volumes about his monumental achievements.

Just as remarkable is David's reputation as a legendary teacher and educator. I had the great fortune of having David as my advisor when I studied computer science at the University of Illinois. His superb tutelage in and outside the classroom, as well as his warmth, humor and wisdom, has had a lasting beneficial influence on me. It is no wonder that over the years, many of his students have become prominent scientists themselves. David once told me that he greatly admired his teacher, the eminent mathematician Professor Gian-Carlo Rota, who always gave lectures that left the audience

* (C) 2014 Computer History Museum, Mountain View, California. www.computerhistory.org. Reference no. X7178.2014, catalog no. 102739932. Reprinted with permission.

† Staff Director, Semiconductor Special Interest Group, Computer History Museum

E-mail: dfairbairn@computerhistory.org incredibly inspired and motivated to think deeper afterwards. David clearly reached that high standard himself, and in addition with a clarity that could not be surpassed. Fittingly, Dave has received the highest accolades as an educator including the inaugural Karl V. Karlstrom Outstanding Educator Award from ACM, the IEEE Education Medal, and the Taylor L. Booth Education Award from the IEEE Computer Society.

Professor Liu has a colorful career that is still going strong. He has been a professor, university president, author of best-selling books, corporation board member, and even popular radio show host. I am proud and thankful to have David as my mentor and close friend, and always look forward to hearing of his next big adventure in life! -Andrew Yao, Tsinghua University

Doug Fairbairn: OK. We're here today at the Computer History Museum. It's Monday, June 2, 2014. I'm Doug Fairbairn, and I'm sitting here with Professor Chung Laung Liu, who has a very rich and interesting background covering many fields, including computer science, mathematics, VLSI design automation, and others, which he is going to share with us. He has been a professor, a teacher, a mentor, and perhaps also equally or more important, a husband, father, and grandfather, which he might also tell us about at the end.

\section{L. "David" Liu: Thank you.}

Fairbairn: He has been a board member and adviser to companies large and small. He's been a university president. And has been and is currently a host on a radio show.

Liu: That's correct. 